\title{
THE INFLUENCE OF LINGUISTIC AND EXTRALINGUISTIC FACTORS ON THE DERIVATIONAL POTENTIAL OF SUBSTANTIVES IN THE MODERN UKRAINIAN LANGUAGE
}

\section{Inna Berkeshchuk ${ }^{1}$ \\ Nataliia Ladyniak ${ }^{2}$}

DOI: https://doi.org/10.30525/978-9934-588-15-0-105

\begin{abstract}
Today, the issue of identifying the typology of word formation, which is based on the functional load of the formative words, becomes relevant for the development of Ukrainian derivatology, and its solution is possible only within the framework of a recently developed approach. In word formation, it is called base-centric because it is focused on the stem as a typology-based factor. The purpose of the base-centric direction is to describe the derivational potential of different classes of formative lexemes, to specify the linguistic and extra-linguistic factors that determine their word-forming ability. The research goal is to identify the structural and semantic typology of the relevant noun units, find out the factors that regulate the derivational capacity of Ukrainian names of trade tools, body parts and metals. The key tasks are as follows: to analyse the factors influencing the word-forming ability of formative nouns; to consider the semantic correlation of formative nouns and their derivatives; to study ways and means of realization of derivational meanings of the desubstantives. The research subject is linguistic and extralinguistic factors of producing lexemes from names of trade tools, body parts and metals. The study materials can be used in derivation studies when describing a derivative family of words, for characteristics of the word-formation system of desubstantives in the papers of monographic nature. Findings and materials can be used for the compilation of morpheme and word-forming dictionaries as well as academic courses on morphemics and word-formation and in relevant
\end{abstract}

\footnotetext{
${ }^{1}$ Candidate of Philological Sciences, Associate Professor, Senior Lecturer at the Department of Ukrainian Language, Kamianets-Podilskyi Ivan Ohiienko National University, Ukraine

${ }^{2}$ Candidate of Philological Sciences, Associate Professor,

Senior Lecturer at the Department of Ukrainian Language,

Kamianets-Podilskyi Ivan Ohiienko National University, Ukraine

(C) Inna Berkeshchuk, Nataliia Ladyniak
} 
textbooks and study guides. Ukrainian names of trade tools, body parts, and metals are included in the lexical system of the Ukrainian language as lexical-semantic groups of words. Taking into account the semantic characteristics of the formative words under consideration, their structural and functional parameters, it is defined the dominant factors that influence the word-formation capacity of the studied groups of formative bases. They are as follows: lexical semantics of formative words, symbolic nature of meanings, stylistic marking, synonymous character, derivation / nonderivation, system substitution (it refers to derivative's redundancy given that a derivate with another formant is formed from another formative word but with the same meaning or common functional lexical unit of non-word formation structure takes its place in the lexical system of the language). Implementation of the outlined semantics by derivatives originating from the names of trade tools, parts of the body and metals is due to a variety of means among which suffixation dominates. The means of word formation are also prefixes, confixes (especially when creating derivatives from somatisms), postfix -cя, which is combined with suffixes or confixes. Compound derivatives are formed by word-, compounding or word-, compounding with suffixation elements.

\section{Introduction}

For a long time, the key role in the systematization and classification of derivatives as well as their structuring was given to a word-formation morpheme that performs classification, conceptual, clarifying, semantic and evaluationstylistic functions, and the role of the derivational base has been ignored.

At the present stage of the development of Ukrainian derivatology, the issue of identifying the typology of word formation, which is based on the functional load of words, becomes relevant, and the solution of this issue is possible only within the framework of the approach that has been formed recently. Word-formation calls its base-centric because it is oriented on the formative base as a typological factor. The purpose of the base-centric direction is to describe the derivational potential of different types of formative lexemes, to find out linguistic and extra-linguistic factors determining their word-formation capacity.

The reference to the noun as a formative base is because the noun and verb as the central parts of the language form the nucleus of the word- 
formation base of Ukrainian derivation, and the names chosen for the study represent a large layer of Ukrainian vocabulary whose denotations play an important role in human life. The selection of the mentioned three groups of formative words is due to their different semantic-grammatical characteristics that allow identifying the factors that determine the derivative behavior of formative words and influence their word formation power.

The research goal is to identify the structural and semantic typology of the relevant noun units, find out the factors that regulate the derivational power of Ukrainian names of trade tools, body parts and metals.

According to the purpose in view, there are specific tasks:

- to analyse factors which influence the word formation capacity of formative nouns;

- to consider semantic correlation of formative nouns with their derivatives;

- to study the ways and means of implementation of word-formation meanings of the specified desubstantives.

The research object is noun-based word formation of the modern Ukrainian language.

The research subject is linguistic and extra-linguistic factors producing lexemes from the names of trade tools, parts of the body and metals.

Lexical-semantic groups of the names of trade tools, parts of the body and metals, which are characterized by the common nature of general categorical meaning of objectivity, are contrasted each other with a number of lexical and grammatical features that affect their derivative potential, determine the corpus of word-formation meanings with which derivatives from the specified group of formative words can be formed. Such groups of formative words are a good basis for a multifaceted study of the wordforming capacity of nouns as a class of formative words.

Base-centric studies of the derivational potential of nouns imply the separation of the studied formative words from the substantive space, their inventory, the establishment of quantitative composition and intragroup structuring and characterization of semantic-grammatical peculiarities which are important in terms of their influence on word formation.

The complex unit of definition and description of word formation capacity of classes of formative words is the word formation paradigm. The range of semantic positions of the typical word-formation paradigm of the names 
of trade tools, parts of the body and metals and their realization by specific formative words, length and depth of positions objectify the derivative behavior and word-formation productivity of the formative words under consideration.

\section{The aspects of factors study}

The base-centric study of word formation involves the establishment of factors which regulate the word-forming behavior of different classes of formative lexemes. The identification of such factors is important in modern derivatology because it allows to establish certain patterns of word formation processes, in particular, in derivation from the names of trade tools, parts of the body and metals, to predict the formation of new derivatives, to find out the reasons for failure of word-formation capacity of root words in the individual semantic positions etc.

The issue of factors regulating the word-formation behaviour of formative words has been studied by a large number of scholars, however, at the present stage, it is still insufficiently studied. Thus, in Russian linguistics, the following scholars have dealt with the issue under consideration: O. Zemska [5], I. Myloslavskyi [11], V. Lopatin [9], I. Ulukhanov [12], L. Denysyk [3], M. Kapral [6] et al. In Ukrainian linguistics, V. Greshchuk [2], N. Klymenko [8], O. Mykytyn [10], I. Dzhochka [4], R. Bachkur [1] et al. have studied the issue. In Ukrainian adjective-base word formation, special attention is paid to the semantics of formative adjectives, their structural characteristics and valence in all their manifestations: "The system factors that determine the word-formation behavior of a formative word are semantics and compatibility of a formative word closely related to it" [2, p. 9]. According to N.F. Klymenko, one of the factors which influence the derivative behavior of a word is a degree of word formation. It is found that the farther the derivative from the top member of word family is, the lower its word-formation capacity is: "The simpler the structure of a word-formation model is, that is, the smaller the degree of word-forming transformations of a base within a model is, the more words interpret it in the language... Increase in complexity of the model and degree of transformation of the base is accompanied by a decrease in the number of words which translate this word-formation model" [8, p. 19].

Studying the derivative behavior of nouns, the authors determine the following set of factors of their word-formation capacity: quantitative 
parameters and qualitative composition of specific word-formation paradigms of different lexical-semantic groups of nouns depend on the lexical and grammatical semantics of the top word, its phonomorphemic structure, activity and sphere of functioning in the language and parole, origin etc. Semantic-syntactic links also determine the word-formation behavior of a formative noun.

O. Mykytyn also defines the similar set of factors of noun-based derivation (names of relatives and affinal relations, names of liquids and abstract nouns) stating that "the realization of derivative potential by specific nouns depends on their semantic and pragmatic factors and conjunctive capacity. The affiliation of a formative noun to the appropriate subgroup of a lexicalsemantic or structural-semantic group is important when interpreting wordforming capacity... The word-forming capacity of formative nouns is directly related to their compound capacities, which depend on semantics of roots. Establishing the factors that determine the implementation of the relevant typical word-formation meaning by specific nouns, the authors also take into account the structural features of the formative words and pragmatic characteristics that correlate with frequency. Often, the lack of some derivatives is because the fact that the relevant meaning is adequately rendered by non-derivative means" [10, p. 164].

Studying the word-formation potential of borrowings in the modern Ukrainian language, L. Kysliuk also concludes about "the dependence of word-formation potential on borrowing age... A large array of borrowings in the Ukrainian language has zero word-formation realization. It is commonly caused by relatively recent age of borrowing or by the lack of a social need in a particular word" [7, p. 12].

Analyzing the word-formation capacity of verbs of a particular physical action with the semantics of object creation, I. Dzhochka notes that "an important system factor that determines the word-formation potential of verbs is their valence characteristics. Formative derivatives can form only those derivatives whose meaning is provided by the valence structure of the motivating word" [4, p. 164], and observations of the word-formation capacity of destructive verbs also make it possible to state: "dominant factors that determine derivational transformations of source units are their semantics and valence closely related to its" [4, p. 55]. "...valence properties of the base play an important role in the derivative processes..." [4, p. 64]. 
"The nature of the word-formation potential of the noun mainly depends on its semantic structure: the subject-identifying or denoted names, the denotative or significative nature of semantics, the type of relation to the referent (ontological, functional or epistemic)" [5, p. 24]. Most Russian scholars consider a semantic component as the main factor that correlates with the word-formation capabilities of different classes of formative words, including nouns: "different factors influence the implementation of word-formation capabilities of nouns but semantic constraint of their co-occurrence with affixes plays the central role" [6, p. 69]. When analysing word-formation capabilities of nouns of substantives, I.H. Myloslavskyi also draws attention to the semantic factor: "...the ability to realize ... the meaning in the derivative depends on the semantic characteristics of the formative words" [11, p. 148].

O. Zemska defines general characteristics that are common to the word formation of different lexical and grammatical groups of words: "Such common features are observed in the structure of word-forming paradigms of different parts of speech: 1) well-used words have more abundant word-forming paradigms than rare words; 2) neutral words have broader paradigms than connotative words; 3 ) words which have free co-occurrence have broader paradigms than words with a constraint co-occurrence; 4) words that relate to human goal-directed activity, spheres important for human life have broader word-forming paradigms than words that name phenomena of another variety" [5, p. 16].

Analyzing the word-formation ability of Russian names of persons, M. Kapral notes that "the most important factor is the motivation / nonmotivation of the names of persons. The valence of non-motivated units is 2.2 times higher than the valence of motivated ones" [6, p. 7].

Besides these factors, there are others which cause high or low wordformation valence of names of persons, in particular: "motivation / nonmotivation of original names of persons, their word-formation structure and degree of word-formation (for derivatives), number of lexical meanings, inclusion in antonymic pairs, functional-stylistic properties, origin (specific Russian - foreign names of persons), phonetic length (number of syllables), nature of the final of the basis, "dominance" (ability of the name of the person to act as a dominant in synonym chain), affiliation to epicene" [6, p. 6-7]. 
Studying Russian material nouns, L. Denysyk notes: "Word-formation potentials of material nouns are affected by morphological, word-formation, morhonological, semantic characteristics of motivational bases, their belonging to limited vocabulary, the novelty of a large part of the studied, especially terminological vocabulary, and factors that adversely affect the word-formation capabilities of the formative bases are their derivative and semantic motivation" [3, p. 13].

N. Yusupova also marks similar set of factors which influence the wordformation capacity of formative words. She emphasizes semantic and formal, structural and word-formation constraints as well as stylistic and lexical ones. These factors "affect the co-occurrence of bases with affixes" $[13$, p. 6]. The scholar believes that semantic factor is the most essential, which she sees in the inconsistency of morphemes' meanings.

$\mathrm{N}$. Yusupova determines the following formal constrains: peculiarities of the sound and syllabic composition of derivatives: a) the nature of the final sound of the base, including the availability of certain conjugations of consonants at the end of the base; b) possibility of alternations; c) number of syllables; the place of emphasis in the formative and possible derivative [13, p. 8].

There is a distinct typology of word-formation capacity established by R.Bachkur who marks 2 groups of factors. The first group includes different features of formative words as units of lexical and grammatical language system: polysemy / monosemy, connotative nature / neutrality, symbolism / non-symbolism, dominance / non-dominance, synonymy / non-synonymy, derivation / non-derivation, large phonetic length / small phonetic length, structural-morphological complexity / structural-morphological simplicity, foreign origin / non-foreign), the availability of a complete inflectional paradigm / defective nature of inflectional paradigm, stylistic and functional neutrality / stylistic-functional markedness (dialectal, vernacular, colloquial, obsolete, etc.) [1, p. 150].

The second group consists of extra-linguistic characteristics of denotations which are represented by the analyzed formative words. Such characteristics (religious-mystical use of a plant or animal (in cults, ceremonies, arcane rites, etc.) / religious-mystical unmarked nature of name of an animal or plant; frequency / non-frequency reflecting the importance of denotation in human activity; distribution of an animal or plant in Ukraine / exotic, ornamental plant or animal; extinct species of 
plant or animal / currently available species of plant or animal; domestic (cultivated) animal or plant / wild (wild) animal or plant; taxonomic class of plant or animal [1, p. 164]) also indirectly influence the word-formation capacity of formative nouns.

Thus, the above set of factors which regulate the word-formation capacity of some lexical-thematic groups is quite full, but it doesn't reflect all reasons which are peculiar to the thematic groups under consideration: names of trade tools, names of parts of the body and names of metals. For this very reason, it is essential to specify and update them.

\section{Factors of word-forming behavior of the names of trade tools, body parts and metals in the modern Ukrainian language}

Ukrainian names of trade tools, body parts, and metals are included in the lexical system of the Ukrainian language as certain lexical-semantic groups of words. Taking into account the semantic characteristics of the studied formatives, their structural and functional parameters, the authors determine the dominant factors that influence the word-forming capacity of the studied groups of formatives.

They are as follows: lexical semantics; symbolic nature of meanings; stylistic marking; synonymous character; derivation / non-derivation; system substitution (it refers to derivative's redundancy given that a derivate with another formant is formed from another formative word but with the same meaning or common functional lexical unit of non-word formation structure takes its place in the lexical system of language).

Lexical semantics. First of all, the possible set and quantity of potential derivatives depends on the affiliation of the formative substantive to a particular lexical-semantic group and the nature of the lexical semantics of the names of trade tools, somatisms or metals.

The names of agricultural trade tools and the names of resident (household) tools produce the highest number of derivatives among the names of trade tools: голка (голочка, голкар, голковий, голчаний, голкоподібний, голчастий (in 1 meaning), голчастий (in 2 meaning.)), граблі (грабельки, граблики, грабляр, грабилно, граблина, граблище грабельний, граблистий (coll.)), лопата (лопатка, лопаточка, лопатник, лопатилно, лопатний, лопатити), мітла (мітлище, мітляр, мітлище, мітлиця, мітловий, мітлоподібний, мітластий) еtс. 
The most productive names of external body parts are as follows: голова (голівка, головка, головище, головешка (in 2 meaning), наголовник, наголовок, приголовчик, головань, головач, головко (coll.), зірвиголова, крутиголова, пробийголова, урвиголова, узголів'я (узголов'я), приголів'я (приголов'я), приголовач, головний, білоголовий, бритоголовий, круглоголовий, пло(а)скоголовий, пустоголовий, русоголовий, сивоголовий, срібноголовий, твердоголовий, тупоголовий, чорноголовий, головоломний, одноголовий, п'ятиголовий, тисячоголовий, дубоголовий, собакоголовий, головатий (головастий), безголовий, стрімголов (in 1 meaning), сторчголов, суньголов) and others.

Among the names of metals, the very metals are most productive than the names of alloy materials. Алюміній realizes the derivational potential to the fullest extent possible (алюмінат, алюмель, алюмінід, алюмінон, алюмофосфат, алюмогель, алюмосилікати, алюмоферит, алюмінієвий, алюмоамонієвий, алюмокалієвий, алюмокобальтмолібденовий, алюмокремнієвий, алюмонатрієвий, алюмокельмолібденовий, алюмооксидний, алюмоплатиновий, алюмінієорганічний, алюмінотермічний, алюмінієвий, алюмініювати, алюмінувати) еtс.

Symbolism of formative lexemes. The names of production tools, especially those which are used in agriculture, the names of household items have a symbolic nature for Ukrainians. Thus, the noun $\kappa o c a$ is a symbol of death, fatality in pan-European tradition, and an old woman with the scythe is the personification of Grim Reaper.

It is quite often observed the development of a symbolic component in the semantic structure of the body parts.

Among the names of internals, cepue is most commonly used in the national symbolism. It is obvious that these symbolic components contribute to the formation of a series of diminutives from the formative cepue (серденько-серденя-сердечко), which are used, e.g. as address pronoun in folksongs (cf. «Соние низенько, вечір близенько, вийди до мене, моє серденько» (folksong).

In Ukrainian culture, there is a figurative perception of чуба, чуприни as a symbol of male beauty, courage, dignity (it is associated with the Cossack habit to grow a scalplock). Byca are also reflected in the expressions with the content "brain, restraint, calm, attention", c.f. мотати на вус, and в вус не дути еtс. 
Significant internal content has such names of the body parts as око, губи, брови, ніс, коса. Thus, the word-symbol око is understood as the concept of all-seeing nature; the word-image of губа is associated with vanity; брови indicate dissatisfaction, anger; нiс in Ukrainian culture is the personification of human arrogance, haughtiness, inquisitiveness. The image of коси is considered by Ukrainians as a symbol of virgin beauty and honor.

Symbolic layers in the semantics of the names of body parts contribute to the productivity of formative lexemes.

Among the names of metals, the images of золота and срібла, which represent something of value, beauty, prosperity, high praise, are widely used in Ukrainian symbolism. The word золото is often used as an address to a loved one. Words-images золото and срібло frequent make up one complex (срібло-злото).

Stylistic markedness. The semantic structure of the analyzed groups of formative words, in addition to the direct lexical meaning, includes special, terminological, dialect, colloquial, obsolete, etc. The stylistic markedness of the analyzed formatives mainly causes a limitation of their word-forming capacity. Affiliation of the formative word to the class of rare, obsolete, colloquial, vulgar ones, etc. causes its limited use, and hence the weakening of word-forming capabilities, the degree of realization of which depends on the needs for communication.

Among the various names of trade tools, it is marked many connotative words characterized by low (and even zero) word-making ability. There are 124 lexemes. Special nouns (marked spec.) are the most noted, and dialect formations and formative words which are used in the technical branch and everyday speech are numerous. For example, рискаль, бук (in 2 meaning), конопатка, скісок аnd others.

Most of the above words are unproductive in the context of derivation. Among the connotative names of trade tools, the most productive words are the noun monip (historicism (in 1 meaning), dialecticism (in 2 meaning)) (топірець (топорець $\left.{ }^{l}\right)$, топірчик, топорисько, топорище) and the archaic lexeme рало (ральце, ралиця, ралити).

In the lexicographic papers of the Ukrainian language, many of the names of trade tools are marked as spec., mining, text., mech. and others. Such formatives are derivationally unproductive or their performance is 
represented by individual derivatives, c.f.: желонка (mining) - желонник, конопатка (spec.) - 0 derivatives and others.

Proceeding from abundance of the names of trade, the dictionary marks the lexemes from the ancient tools: диба, кельт ${ }^{2}$, різець, рубило and скребло. These names are inert in the context of word-formation. The word-formation unproductiveness of the analyzed units is caused by the lack of denotations. Дрюк and палиия are primitive, ancient. However, compared to archaic tools диба, кельт ${ }^{2}$, різець, рубило and скребло, these nominations are still used in the practical life activity of speakers that leads to the derivational capacity of formative words (дрюк - дрюччя, палиия - паличка, паліччя, паличний). Temporal introduction of trade tools is reflected in the derivational ability of agricultural manual tools and agricultural names of mechanized ones. More productive are the names of manual tools. Mechanized tools were available later after the improvement of technologies that influenced the development of derivatives.

The same tendency is observed in the names of body parts. Among somatisms, there are few formative lexemes which are denoted in the lexicographical literature with marks anatomy, biology, which have low or zero zero productivity. For example, common nouns are derivatively unproductive - глотка (anatomy) - носоглотка, епістрофей (anatomy) - 0 derivatives, стремено (anatomy) - 0 derivatives, суреля (anatomy) 0 derivatives, яŭuепровід (biology) - 0 derivatives and others.

There are 119 formatives of connotative words among the names of body parts where one can note a lot of colloquial, dialectic and anatomic names: бабешки, баки, бакени, балухи, банька², баньки, башка, бебехи, бельбахи (бельбухи), борлак and others.

Among connotative words, colloquial names are empowered with maximum derivational potential (вирла, в'язи, пазуха - вирлач, вирлатий; в'язний, в'язистий; пазушка, пазушний) and dialectic ones (циба, хава цчибань, циибатий, циибати; хавка, хавкати). Other formatives are not productive.

As compared to the names of trade tools and somatisms, some ancient names as well as modern ones are productive among the names of metals. It is noted such lexemes: вісмут, гірчець, курчатовій, марганець, оливо1, серебро, спиж ${ }^{2}$, сребро, иина. Almost all their modern equivalents are productive. 
The productivity of metal lexemes is associated with the fact that formatives and derivatives are widely used in specialized (mostly chemical) literature. In other words, professional literature needs the availability of relevant derivatives - terms denoting different metal goods, metal compounds and others.

Thus, conducted research gives the reason to state that the factor of stylistic markedness stipulates lexical-semantic group of metals name in the word-formation context, and it is rendered partially in lexical-semantic group of the names of trade tools and somatisms; in some cases, it hinders their derivative potential.

Synonymous character of the formative words under consideration. In addition to the analyzed characteristics of the formative word (symbolism of semantics, stylistic markedness), its word-forming ability is influenced by the availability or lack of synonyms for formative names. Usually, in the synonymic chain of formative words, the dominant lexical unit of the synonymic chain manifests word-formation productivity, and others are ineffective or do not produce derivatives at all.

Thus, there are such names of manual tools: барда, бартка, сокира, тесак, топір найбільшою продуктивністю характеризується субстантив сокира (сокирка, сокирчина, сокирисько, сокиряка, сокирник, сокирище, сокирки, сокирний, сокирячий). The noun monip produces the derivatives (mопорецьв ${ }^{I}$ ), топірчик, топорисько, топорище. Other formative lexemes don't realize their derivational potential.

Among the names of body parts, it is marked the following synonymous chain: живіт (животик), черево (черевце, черевина, начеревник, підчеревник, черевань. підочеревина, підчеревина, черевний, череватий, голічерева, догоричерева, долічерева), пузо (пузие, пузан, пузань, голопузий, товстопузий, пузатий), лоно (0 derivatives), вирла (вирлач, вирлатий), сліпи (0 derivatives) and others. Consequently, the specific nature of formative synonyms is that mainly one or two lexemes are active in the part of word-formation, and others act as inactive lexemes at the level of word-formation.

Among the names of metals, there are many lexemes that are synonymous. In fact, only one member of the synonymous chain is productive in the context of word-formation, and other synonyms are characterized by low word-formation ability or are inactive in word-forming. 
Structural complexity, derivative / non-derivative nature. The research of SD of the names of trade tools, body parts and metals confirms the general tendency according to which the simpler lexeme is in its composition and structure, the more dynamic its involvement in the processes of word creation is. Compound words are characterized by low word-formation capacity. The vast majority of analyzed formative lexemes are unproductive in the context of word-formation, in particular: бурякокомбайн, бурякокопач, бурякомийка, бурякорізка, бурякопідіймач, валкоутворювач, газонокосарка, електроплуг; стравохід, яйщепровід; екавольфрам and others.

The factor of "derivative / non-derivative nature" of the substantives under consideration is closely related to the structural complexity of formative lexemes. At the same time, there is the following consistency: non-derivative formative words denoting the names of tools, body parts and metals form the core of their word-formation base in modern Ukrainian, and derivative formatives - periphery, c.f.: чаплія - чаплиїльно, чаплійка; шарошка - иарошечний, шарошковий and others, but льономолотарка - 0 derivatives, льоносівалка - 0 derivatives and others; бік - бочок, бокастий (бокатий); кулак - кулачок, кулачище, кулачки, кулачний but носоглотка - 1 derivate (носоглотковий), очеревина - 1 derivate (очеревинний); ртуть - ртутний, ртутити but екавольфрам - 0 derivatives and others.

System substitution. Among the names of trade tools, there are few formative words that denote the same subject. On the basis of such lexemes names of trade tools, mainly one-two derivatives are productive; however, there are nouns pairs which are formed by the derivatives from two names. As a formative word батіг produces the derivatives батіжок, батожилно, батожистий, батожити, there are odd ones in the lexical system, for example: *байбарачок, *байбаристий, *байбарити and others. Derivatives with the meaning of "act using one what is called a formative" cannot be expected from such names of trade tools as гарапник, малахай, nyza because it is produced the derivate with the indicated semantics from the noun бич-бичувати. A derivate *лопатити is not formed from лопа$m a$ with the same meaning as there is a formative копати; *лопатор, c.f. плугатор because there is копач.

Among the somatisms, there are, for example, lexemes рука, лівиця, правиия, иульга, лапа and others. The derivatives are produced from the 
formative рука (ручки, рученята (pl.), ручка, руия, ручиця, ручисько, ручище, наручники, наручні, наруччя, підручник, поручата, поручі, поручні, поруччя, рукав, рукавичя, руків 'я, рукоятка, рукоять, рукохід, рукоблудник, ручний, білорукий, довгорукий, криворукий, сухорукий, тонкорукий, рукоблудний, рукодайний, рукопашний, рукописний, рукотворний, однорукий, сторукий, рукатий, ручкатися, рукоблудничати, власноручно, вправоруч, врукопаш (рукопаш, врукопашну), нашвидкоруч, обіруч, одноруч, саморуч, голіруч, попідруки, попідруч, попідручки). Other formative lexemes didn't realize their derivational potential. Taking into account the availability of derivatives produced from the noun рука, it is not necessary to create derivatives from other lexemes with the same meaning. Thus, we often use the lexeme рука instead of правиия, лівиия and others, or we can use the combination of words права рука, ліва рука.

Nouns denoting metals have alternative pairs of synonyms. In speech, people more often use such metal names as залізо, золото, мідь, срібло etc. that influences a high productivity of these formatives. Names pepys, аурум, купрум, аргентум саn't produce derivatives. The factor analyzed also influences the use of plural forms in metal names.

Important factors that determine the word-forming conduct of the analyzed word classes are non-linguistic factors, in particular, the importance of a specific denotation, which is verbalized by the formative, in economic and practical activity and human activity. Under the framework of the identified groups of vocabulary, it is possible to distinguish a number of formative words that indicate important metals for humans (залізо, золото, срібло еtс.), most commonly used tools (коса, лопата etc.), body parts under consideration which were endowed with various mythical and associative-figurative properties (рука, око, язик, серие etc.).

Ukrainians are traditional grain-growers, farmers, and for this very reason, instruments and tools that facilitate work during agricultural activities are of particular importance to us. The names of such tools are highly productive. Household tools which are used for cleaning, cooking etc. are also productive.

The importance of body parts for the human outlook is related to the anthropomorphic thinking of ancient Ukrainians, humanization of the environment, etc. in view of this, human emotions and feelings are projected into separate parts of the body (love or other emotions - cepuse (heart); pain, 
hatred - зуби (teeth) (“to grit”); fear -ноги (legs) (“серце в п’яти”, “ноги на плечі", etc.), attention - вухо (ear); relationships between people are also "materialized" by referring to parts of the body (people welcome by shaking hands etc.). The names of such parts of the body are the most ancient in the language (since Proto-Indo-European or Slavic period) and they produce a large number of derivatives, for example: рука (ручки, рученята (pl.), ручка, руия, ручичя, ручисько, ручище, наручники, наручні, наруччя, підручник, поручата, поручі, поручні, поруччя, рукав, рукавичя, руків'я, рукоятка, рукоять, рукохід, рукоблудник, ручний, білорукий, довгорукий, криворукий, сухорукий, тонкорукий, рукоблудний, рукодайний, рукопашний, рукописний, рукотворний, однорукий, сторукий, рукатий, ручкатися, рукоблудничати, власноручно, вправоруч, врукопаш (рукопаш, врукопашну), нашвидкоруч, обіруч, одноруч, саморуч, голіруч, попідруки, попідруч, попідручки).

As for metals, on the one hand, those, which had been used in the farming long ago (залізо, сталь), have performed and perform the function of money (золото, срібло) еtc. are important for speakers. On the other hand, they began to be actively used in the modern industry that led to the origin of new products, alloys, etc., which are nominated by the analyzed derivatives. Thus, алюміній produces 22 derivatives (алюмінат, алюмель, алюмінід, алюмінон, алюмофосфат, алюмогель, алюмосилікати, алюмоферит, алюмінієвий, алюмоамонієвий, алюмокалієвий, алюмокобальтмолібденовий, алюмокремнієвий, алюмонатрієвий, алюмокельмолібденовий, алюмооксидний, алюмоплатиновий, алюмінісорганічний, алюмінотермічний, алюмінієвий, алюмініювати, алюмінувати), залізо ${ }^{1}-20$ derivatives (залізобетон, залізографіт, залізопорфирін, залізоцемент, заліза (pl.), залізко (in 1 meaning.), залізие, залізяка, залізний, залізоамонійний, залізовуглецевий, залізорудний, залізонікелевий, залізохромовий, залізоплавильний, залізопрокатний, залізоробний, залізовмісний, залізистий, залізний), золото ${ }^{l}-14$ derivatives (золотие, золотник ${ }^{l}$, золототисячник, золотар, золотодобувач, золотошукач, золотопромисловець, золотий (in 1 meaning), золотоносний, золотосяйний, золототканий, золотовмісний, золотий, золотити (in 1 meaning)), платина - 11 derivatives (платинат, платиніт, платиноїди, платиноз, платинотипія (special), платиновий, алюмоплатиновий, платинохлористоводневий, платиновмісний, платиновий, платиноподібний), срібло ${ }^{1}-22$ derivatives (срібник 
(in 2 meaning), срібняк, срібляк, срібляник (у 2 знач.), сребреник, срібляр, сріблолюбечь, срібний (in 1, 3-7 meanings), сріберний, срібряний, сріб'яний, сріблоорганічний, сріблолюбний, сріблоносний, сріблоплавильний, сріблотканий, срібносяйний, срібловмісний, сріблистий, среб'яний, срібляний (in 1 meaning), сріблити (in 1 meaning)), сталь - 15 derivatives (сталініт, сталебетон, сталевар, сталеливарник, сталеплавильник, сталепрокатник, сталетопник, сталеливарня, сталетопня, сталевий, стальний, стальовий, сталевий, сталити, сталювати), уран ${ }^{2}-$ 12 derivatives (уранат, уранізм, ураніл, уранініт, трансурани, актиноуран, уранопластика, уранофобія, урановий, уран-графітовий, урановмісний, урановий) and others.

Consequently, formative words whose denotations are less important for the ordinary speaker (for example, narrowly specialized instruments, names of devices, tools, equipment, etc., names of individual bones in the ear or nose, tumors, names of skin cover, muscles, glands, and parts of nerve systems, metals - lanthanides, etc.) are either ineffective or inactive in the context of word-formation. For example, the lexemes флюгер, форсунка, чесалка and others; епістрофей, кадик, кукса, панкреас, райдужка аnd others; гірчеиь (archaic), станум еtc. don't produce lexemes.

Thus, the importance of the names of trade tools, parts of the body and metals in the farming and human activity has a positive impact on the word-forming ability of the analyzed groups of formative words.

According to scholars, the importance of some objects in the life of a speaker is represented by the frequency of the use of lexemes which denote them. Thus, V.Greshchuk states that communicative needs reflect the importance of words in human practice, and it correlates with the frequency of words' use in speech. The word with a higher frequency has a higher probability of the production of the derivative based on the formative word. Therefore, when analyzing the derivative capacity of different word classes, and, in particular, the names of trade tools, somatisms and metals, it is necessary to pay attention to the frequency of the formative word, which affects the communicative needs of the speaker. However, a frequency dictionary of the Ukrainian language fixes the frequency of lexemes' use only in artistic texts, not taking into account the various technical, anatomical and chemical study guides and manuals, so the data from this dictionary should be used with relevant amendments. 


\section{Conclusions}

The factors which influence the derivational potential of formatives are objectified in word-formation paradigm, and capabilities of word-formation potential determine a type of the derivational paradigm. Among such factors, the author marks linguistic (it includes a variety of lexical and grammatical categories, which are peculiar to the analyzed formatives, special aspects of stylistic functioning, structural complexity and derivative/ non-derivative nature of the analyzed names of trade tools, parts of the body and metals) and extra-linguistic, which are related to the importance in the farming and economic and practical human activity and life.

The research found that there are some factors which are associated with high productivity of a formative word (lexical semantics, non-formative nature, economic and practical use). Some of the factors, on the contrary, slow the formation of derivatives and affect the low derivative potential (stylistic markedness, the inability of combining lexemes' stems with some affixes, the structural complexity of the formative lexeme, and the redundancy of the derivative).

It is worth noting that some of the factors are manifested variously in the different thematic analyzed groups. For example, stylistic markedness of word-formation derivatively stimulates the lexical-semantic group of metal names, while in the lexical-semantic group of the names of trade tools and somatisms it reflects partially, and in some cases, it inhibits their derivational potential.

It is marked the complex character of factors action. For example, zero productivity of a formative гірчищь is influenced not only by the availability of a synonym магній but also the archaic nature of the very lexeme гipчиць (с.f. олово - цина and others). Such factors as the symbolism of the formative word and the importance of the particular denotation, which is verbalized by the formative word in economic practice and human activity, influence the high productivity of the formative рука, etc.

The analysis of the typical and specific word-formation paradigms of Ukrainian names of trade tools, body parts and metals showed that the analyzed formatives are quite active in the context of word-formation, but they realize their derivative potential in different ways. None of the analyzed nouns form derivatives with all typical word-forming meanings. Linguistic and extra-linguistic factors have a strong hold over the derivational 
potential of the names of trade tools, body parts and metals in the modern Ukrainian language. The paper marks 5 oppositions among linguistic factors, which influence the word-formation ability of the analyzed substantives, and 2 oppositions among extra-linguistic oppositions. Such factors are linguistic (they involve different lexical-grammatical categories, which are peculiar to the analyzed formatives, special aspects of stylistic functioning, structural complexity and derivative / non-derivative nature of the names of trade tools under consideration, body parts and metals) and extra-linguistic which relate to the importance in trade and practical activity and human livelihood and lexical semantic formative. The analysis of derivational paradigms of Ukrainian names of trade tools, body parts and metals updates the available studies on the noun derivatives on the grounds of the basic-centric word-formation of the modern Ukrainian language. Follow-up studies of the derivative potential of other groups of formative nouns will make it possible to find out the full typology of Ukrainian substantive word formation.

\section{References:}

1. Bachkur, R.O. (2004). Struktura slovotvirnykh paradyghm ukrajinsjkykh nazv tvaryn ta roslyn [Structure of word-forming paradigms of Ukrainian names of animals and plants] (PhD Thesis), Ivano-Frankivsk.

2. Greshchuk, V.V. (1995). Ukrainskyi vidprykmetnykovyi slovotvir [Ukrainian adverbial word formation]. Ivano-Frankivsk: Plai.

3. Denisik, L.N. (1988). Slovoobrazuyushchiy potentsial veshchestvennykh sushchestvitel'nykh v sovremennom russkom yazyke [The word-forming potential of real nouns in modern Russian language]. Kyiv.

4. Dzhochka, I.F. (2003). Deryvatsiinyi potentsial diiesliv konkretnoi fizychnoi dii z semantykoiu stvorennia obiekta [The derivative potential of verbs of a specific physical action with the semantics of object creation] (PhD Thesis), Ivano-Frankivsk.

5. Zemskaya, E.A. (1973). Sovremennyy russkiy yazyk: Slovoobrazovanie [Modern Russian language: Word formation]. Moskva: Prosveshchenie.

6. Kapral, M.I. (1997). Slovotvirna valentnist ta slovotvirna paradyhmatyka nazv osib u rosiiskii movi [The word-forming valence and word-forming paradigm of names of persons in Russian language] (PhD Thesis), Kyiv.

7. Kysliuk, L.P. (2000). Slovotvirnyi potentsial zapozychen u suchasnii ukrainskii literaturnii movi [The word-forming potential of borrowing in modern Ukrainian language] ( $\mathrm{PhD}$ Thesis)], Kyiv.

8. Klymenko, N.F. (1984). Slovotvorcha struktura i semantyka skladnykh sliv u suchasnii ukrainskii movi [Word-structure and semantics of compound words in modern Ukrainian language]. Kyiv: Nauk. Dumka. 
9. Lopatin, V.V. (1977). Russkaya slovoobrazovatel'naya morfemika. Problemy i printsypy opisaniya [Russian word-forming morpheme. Problems and principles of description]. Moskva: Nauka.

10. Mykytyn, O.D. (1998). Strukturno-semantychna typolohiia slovotvirnykh paradyhm imennykiv u suchasnii ukrainskii movi [Structural-semantic typology of word-forming paradigms of nouns in modern Ukrainian language] ( $\mathrm{PhD}$ Thesis), Ivano-Frankivsk.

11. Miloslavskiy, I.G. (1980). Voprosy slovoobrazovatel'nogo sinteza [Questions of word-formation synthesis]. Moskva: Izd-vo MGU.

12. Ulukhanov, I.S. (1977). Slovoobrazovatel'naya semantika v russkom yazyke i printsipy ee opisaniya [Word-forming semantics in Russian language and principles of its description]. Moskva.

13. Yusupova, N.G. (1980). Struktura slovoobrazovatel'nykh paradigm imen sushchestvitel'nykh v sovremennom russkom yazyke [Structure of word-forming paradigms of nouns in modern Russian language] ( $\mathrm{PhD}$ Thesis), Moskva. 